\title{
Effects of Nanta Activities on the Adults Who Stutter with Intellectual Disabilities
}

\author{
Yeong Hye Park ${ }^{1,2}$, Kyungjae Lee ${ }^{1,3}$, Seong Hee Choi ${ }^{1,3}$ \\ ${ }^{1}$ Department of Audiology and Speech-Language Pathology, The Graduate School of Health and Health Industry, Daegu Catholic University, Gyeongsan, \\ Korea \\ ${ }^{2}$ \& Mom Language Phycological Development Center, Pohang, Korea \\ ${ }^{3}$ Department of Audiology and Speech-Language Pathology, College of Bio and Medical Sciences, Catholic Hearing Voice Speech Center, Daegu Catholic \\ University, Gyeongsan, Korea
}

\author{
Received: February 11, 2021 \\ Revised: April 5, 2021 \\ Accepted: April 24, 2021 \\ Correspondence: \\ Kyungjae Lee, $\mathrm{PhD}$ \\ Department of Audiology and \\ Speech-Language Pathology, Daegu \\ Catholic University, 13-13 Hayang- \\ ro, Hayang-eup, Gyeongsan 38430, \\ Korea \\ Tel: $+82-53-850-2543$ \\ Fax: $+82-53-359-6780$ \\ E-mail:kjlee0119@cu.ac.kr
}

\begin{abstract}
Adults who stutter (AWS) may have difficulty in coordination of speech-related muscles movement. Therefore enhancement of coordiantion of speech-related muscles may result in a decrease in disfluency. The current study is a case report of two AWS with intellectual disabilities who received Nanta treatment, non-verbal music therapy technique focusing on coordination of muscles. Two AWS with intellectual disabilities received Nanta treatment for 15 sessions. The Nanta treatment is made up of two goals; body movement to rhythm and speech-related movement to rhythm. Disfluency frequencies for conversation samples were measured pre-treatment, every second treatment, and post-treatment. In addition, a communication test was conducted pre- and post-treatment. Both participants showed a decrease in disfluency frequencies. Moreover there were individualized differences in the changing pattern. However, the participants did not show a positive change in communication attitude. The Nanta treatment may have been effective in reducing disfluency frequencies for the participants of the current study, especially because the treatment was based on non-verbal techniques. These results emphasize that stuttering treatment should be individualized according to the client's characteristics.
\end{abstract}

Key Words: Nanta, Stuttering, Intellectual disability, Adults.

\section{INTRODUCTION}

말더듬의 가장 큰 특징은 비유창한 말로 인해 사회적 상호작 용을 하는 데 어려움을 겪는다는 것이다(Guitar, 2018). 또한 말 더듬이 지속되면 다른 사람과의 의사소통과 자기 자신에 대하여 부정적인 감정과 태도를 갖게 된다. 말더듬의 원인에 대해서는 다양한 의견이 있으나 Van Riper(1997)는 말을 산출하기 위한 다양한 기관의 협응에서 어려움을 겪는다고 하였다. 이와 관련 하여 여러 연구자들이 말더듬은 구강움직임과 음성산출, 언어생 성과 관련된 운동 시스템과 관계있다고 보고하였다(Caruso et al., 1988; Loucks et al., 2007; Olander et al., 2010). 이에 말더듬는 사람의 유창성을 증진시키기 위해서는 구어 근육의 협 응을 향상시키는 것을 목표로 한다. 예를 들어 말더듬 성인을 대

(c) This is an Open Access article distributed under the terms of the Creative Commons Attribution Non-Commercial License (https://creativecommons.org/ licenses/by-nc/4.0) which permits unrestricted non-commercial use, distribution, and reproduction in any medium, provided the original work is properly cited.
상으로 하는 대표적 치료 책략 중 하나인 유창성 완성법은 말속 도 조절 등을 이용하는데, 말속도 조절은 여러 조음기의 협응을 향상시키는 것을 목적으로 한다(Conture \& Melnick, 1999; Gottwald, 2010; Guitar, 2018; Zebrowski, 1994). 이와 유 사하게 '음절 박자 말하기(syllable timed speech)'는 각 음절 을 일정한 비트로 박자에 맞춰서 말하는 프로그램으로 음성 산 출 시스템을 안정화시킴으로써 말더듬을 줄이는 데 효과적이라 고 보고되었다(Ingham, 1984; Packman et al., 2000).

이와 관련하여 구어 관련 근육의 협응력을 향상시키기 위하여 말더듬치료에 음악을 활용한 치료활동을 포함할 수 있을 것이 다. 예를 들어 몸 동작을 활용하는 난타활동에 말 활동을 결합 하여 구어 관련 근육의 협응력을 향상시킬 수 있을 것이다. 난타 활동이란 권투시합의 난타전처럼 북을 마구 두드리며 자유롭게 연주하거나 친숙한 음악에 맞춰 함께 연주하는 활동을 말한다 (Heo, 2013). 난타활동을 활용한 음악치료에서는 느린 박자부 터 시작하여 점차로 속도를 높여 북을 치는 활동을 포함하는데 
이러한 활동을 통하여 팔 등과 같은 신체기관의 움직임의 협응 이 향상되었다(Kim et al., 2002). 이에 난타활동에 구어 과제 를 결합시키면 전술한 바와 같은 말속도 조절효과, 음절 박자 말 하기와 같은 효과가 나타나 조음기 협응이 향상되어 유창성 증 진에 도움이 될 것으로 기대된다.

특히 난타활동과 같은 음악치료활동을 말더듬치료에 포함하 면 여러 부수적인 효과와 장점도 있을 것으로 기대된다. 예를 들 어 신체의 적극적인 몸놀림과 연주행위를 통하여 난타활동은 대상자의 스트레스 감소 및 성취감과 자신감의 적극적인 표현의 증가를 유도할 수 있었으며 수업 분위기 역시 향상될 수 있었다 (Lee, 2014; Shin, 2010). 말더듬는 사람은 부정적 의사소통태 도, 낮은 자존감 등을 보이기에 난타활동이 말더듬는 사람의 내 적 특성 증진에 도움이 될 수 있을 것으로 기대된다. 또한 난타활 동은 비언어적인 활동을 포함하기에 유아에서부터 노년층까지 언어 및 지적능력 발달에 어려움이 있는 대상자에게 사용할 수 있다(Choi, 1993; Jung, 2015; Kim, 2003; Kim, 2010; Kim, 2017). 예를 들어 말더듬치료에서 자주 사용되는 말속도, 리듬 과 같은 추상적인 개념을 자신의 손 움직임, 북 소리 등과 관련지 어 구체적인 실례와 함께 지적장애인이 체험하게 한다면 이들의 이해와 활동을 촉진시킬 수 있을 것으로 기대된다. 이에 말더듬 성인, 특히 지적장애가 있는 말더듬 성인을 대상으로 신체 협응 능력 및 구어 관련 근육의 협응력을 향상시켜 유창성을 증진시 키는 데 난타활동이 도움을 줄 것으로 기대되나 아직 이와 관련 된 실증적인 연구가 매우 부족한 편이다.

이에 본 연구에서는 난타활동을 활용한 말더듬치료를 지적장 애를 동반한 말더듬 성인에게 적용한 사례를 보고하고자 하였 다. 이러한 통합적인 말더듬치료 프로그램을 활용한 사례보고를 통하여 지적장애와 같은 동반장애가 있는 말더듬 성인을 대상으 로 하는 치료방법의 다양화에 기여하고자 하였다.

\section{CASE REPORT}

\section{연구 대상}

본 연구는 두 명의 지적장애가 있는 말더듬 성인을 대상으 로 하였다. 참여자 1 은 지적장애 3 급인 20 세 남성이었다. 본 연 구 참여시 Paradise Fluency-Assessment-II (P-FA-II) (Sim et al., 2010)로 측정한 말더듬 중증도는 심함이었다(백분위 점수: 81 90\%ile). 또한 참여자의 언어연령을 고려하여 초등 학생용 의사소통태도평가(Sim et al., 2010)를 실시한 결과 는 12점(백분위 점수: 40 50\%ile)으로 중증도는 중간이었다. Receptive and Expressive Vocabulary Test (REVT) (Kim et al., 2009) 결과, 수용어휘 등가연령은 9세 6 11개월(백분 위 점수: $10 \% \mathrm{ile}$ 미만), 표현어휘 등가연령은 10 세(백분위 점
수: $10 \% \mathrm{ile)}$ 로 나타났다. 참여자 2 는 다운증후군으로 진단되었 으며, 지적장애 2급인 28세 남성이었다. 본 연구 참여시 P-FAII (Sim et al., 2010)로 측정한 말더듬 중증도는 심함이었다 (백분위 점수: 90 99\%ile). 또한 참여자의 언어연령을 고려하 여 초등학생용 의사소통태도평가(Sim et al., 2010)를 실시한 결과는 13점(백분위 점수: 60 70\%ile)으로 중증도는 중간이었 다. REVT (Kim et al., 2009) 결과, 수용어휘 등가연령은 5세 0 5개월(백분위 점수: $20 \%$ ile 미만), 표현어휘 등가연령은 6세 0 5개월(백분위 점수: $10 \% \mathrm{ile}$ )로 나타났다.

\section{연구 절차}

본 연구는 대구가톨릭대학교 생명윤리위원회의 (CUIRB-2019-0058) 승인을 받아 진행되었다. 참여자들은 초 기 말더듬 및 언어평가를 받은지 1 주일 후부터 주 1,2 회(회기당 60 분), 총 15 회기에 걸쳐 난타를 이용한 언어치료를 받았다. 언 어치료는 2019년 12월부터 2020년 4월까지 사설 언어치료실에 서 개별치료로 진행되었다.

연구자는 언어치료 중 대화자료 200음절을 대상으로 100음 절당 비유창성의 유형별 발생빈도를 치료 2 회기부터 측정하였으 며, 이후 치료 2 회기 마다 1 번씩 총 7 회 측정하였다. 또한 15 회기 의 언어치료 종료 1 주일 후, 대화자료를 이용하여 100 음절당 비 유창성의 발생빈도를 측정하였다. 이에 초기 평가, 치료 중 7회 평가, 사후평가 등 총 9회에 걸쳐서 대상자의 비유창성 발생빈도 를 측정하였다. 더불어 초기 말더듬 평가와 사후평가 시 대상자 의 언어연령을 고려하여 초등학생용 의사소통태도평가(Sim et al., 2010)를 실시하였다.

\section{치료 프로그램}

일반적인 난타활동은 대사 없이 리듬, 비트, 상황극 등으로 이 루어진 비언어극이라면 본 프로그램은 난타활동에 말 산출활동 을 추가하여 조음기관을 포함하는 구어 관련 신체기관의 근육 협응력을 향상시킬 수 있도록 구성하였다. 본 연구는 특히 지적 장애인을 대상으로 하기에 다음과 같은 원칙에 따라 난타 프로 그램을 구성하였다(Cho, 2007; Jang, 2015).

첫 번째 원칙은 지적장애인은 진동이 큰 타악기에 더 적극적인 반응을 보인다는 것이다. 예를 들어 북은 진동 같은 울림이 다른 타악기에 비해 강하므로 청각적 감각을 더 잘 자극하고 감정과 정서를 불러일으킬 수 있다. 이에 본 연구자는 북을 이용하였다.

두 번째 원칙은 지적장애인들에게 악기 연주는 인지 및 운동 능력에 맞도록 구성해야 한다는 것이다. 지적장애인들이 성공적 인 경험을 빈번히 경험하여 성취감을 느낄 수 있도록 각 지적장 애 참여자의 기능에 맞게 난타활동 과제를 구성하였다. 예를 들 어 양손 북치기와 같은 난이도가 매우 쉬운 과제부터 시작하여 
참여자가 정반응을 보일 수 있도록 치료를 구성하였다. 특히 참 여자가 정반응을 보일 수 있는 기회를 많이 제공하여 성공이라 는 경험을 늘려서 자존감과 자신감을 높이는 데 도움을 주었다. 또한 참여자의 정반응에 즉각적인 칭찬을 제공하여 참여자 자신 이 성공하였다는 점을 알 수 있도록 하였다.

세 번째 원칙은 주의집중과 지속시간이 길지 않은 악기의 연 주활동을 선택해야 한다는 것이다. 시간이 긴 악곡은 이해와 표 현이 제한적이므로 단순한 패턴 리듬의 반복적인 훈련으로 집중 력과 기억력을 높일 수 있도록 구성하였다. 노래에 북치기나 박 수치기를 통해 리듬을 통한 변별력을 향상시키도록 하였으며 친 숙한 멜로디나 의성어 및 의태어가 들어간 동요를 통해 빠르게 리듬을 습득하도록 하여 적극적인 활동으로 동기부여가 되도록 하였다.

마지막으로 지적장애인을 위한 난타활동은 단순하고 일정한 반복리듬을 사용하도록 구성해야 한다는 것이다. 단순한 리듬과 선율의 경우 모방과 기억이 쉽기 때문에 기억 보조도구로 사용할 수 있다. 리듬패턴과 멜로디를 이용하여 난타활동의 구성을 최대 한 구조화하여 지적장애인들이 긍정적인 경험이 되도록 하고, 가 능한 수준에서 유창성 증진의 목표를 성취할 수 있게 구성하였다.

위와 같은 원칙에 따라 구성한 본 치료 프로그램의 구체적인 치료 목표와 활동은 다음과 같다. 각 회기별 주요 치료 목표와 활동은 Appendix에 수록되어 있다.

\section{박자에 맞추어 신체기관 움직이기}

본 목표는 박자에 맞추어 신체기관을 적절히 움직이는 것을 목표로 하였다. 이를 위하여 난타활동의 소개, 긴장-이완활동, 양손을 이용하여 북 치기, 박자 나누기 등의 활동을 하였다. 긴 장-이완활동은 호흡 조절, 스트레칭 등을 포함하였다. 양손을 이용하여 북치기의 경우 2 8박까지 강약을 조절하여 양손으로 북치기를 실시하였다. 박자 나누기의 경우 북채를 잡은 오른손과 왼손을 번갈아 가며 박자에 맞춰서 북을 치는 활동을 하였다. 이 후 강약 조절과 박자 나누기를 통합하여 오른손, 왼손을 번갈아 가며 강-약으로 북치기를 하였다. 이러한 활동은 치료 1 회기에서 5 회기까지 진행하였다.

\section{박자에 맞추어 말 산출하기}

본 목표는 박자에 맞추어 말을 산출하는 것이다. 이를 위하여 매우 느린 박자에서부터 빠른 박자에 맞추어 양손으로 북을 치 며 한 음절씩 산출하는 훈련을 하였다. 우선 1 음절부터 시작하 여 5 음절 단어 수준까지, 이후 최대 10 음절 문장까지 산출 훈 련을 하였으며 속도 조절훈련도 같이 실시하였다. 이후에 자발 화 산출훈련을 하였다. 본 활동은 6 회기부터 15 회기까지 진행하 였다. 전체적인 치료는 언어재활사 국가자격증 2 급, 음악치료사
1 급의 자격을 소지한, 언어치료 임상경력 5년의 치료사가 개별치 료로 진행하였다.

\section{분석 방법 및 신뢰도}

본 연구에서는 P-FA-II의 기준을 따라 정상적 비유창성과 비 정상적 비유창성을 분석하였으며 이를 바탕으로 200 음절의 대 화자료를 분석하여 100 음절당 비유창성의 발생빈도를 측정하 였다. 정상적 비유창성으로는 주저(H), 간투사(I), 미완성 낱말 $(\mathrm{Ur})$ 이나 수정, 구.어절을 1 2회 반복(R1)을 포함하였으며, 비정 상적 비유창성으로는 비정상적 주저( $\mathrm{Ha})$, 비정상적 간투사(Ia), 비정상적 미완성/수정( $\mathrm{URa})$, 다음절 낱말, 구, 어절 등이 3회 이 상의 비정상적 반복(R2), 낱말보다 작은 단위에서 일어나는 모든 반복을 포함하며, 연장.막힘깨진 낱말을 포함하는 비운율적 발 성(DP)으로 분류하였다.

전술하였듯이 치료 프로그램 시작 일주일 전의 사전평가, 총 7 회의 치료 중 평가, 치료 종료 1 주일 후의 사후평가 등 총 9 회의 평가자료를 분석하여 참여자의 비유창성 변화를 시각적으로 제 시하여 살펴보았다.

비유창성 분석의 신뢰도를 검증하기 위해 독립된 분석자가 참 여자의 분석자료 총 9 회 중 3 개를 분석하였다. 독립된 분석자 는 1급 언어치료사였으며, 평가자간 신뢰도는 P1은 $98 \%, \mathrm{P} 2$ 는 $97 \%$ 로 나타났다.

\section{참여자 1 의 비유창성 빈도와 의사소통태도의 변화}

참여자 1 의 사전평가, 치료 중 평가 총 7 회, 사후평가 등 총 9회의 평가에서 관찰된 100음절당 각 유형별 비유창성 빈도는 Table 1, Figure 1과 같다.

우선 정상적 비유창성의 경우, 사전평가에서는 100 음절당 2.41회 관찰되었으나, 치료 중 전체적으로 증가하는 추세를 보여 14 회기에서는 7.29 회를 보였다. 하지만 치료 종결 1 주일 후 사후 평가에서는 5.83 회 관찰되었다. 하지만 정상적 비유창성의 각 유 형별 변화는 매우 다양한 모습을 보였다. 우선 주저 $(\mathrm{H})$ 의 경우, 사전평가에서 0.48 회, 치료 중 최고 1.46 회까지 관찰되었으며 사후평가에서는 4.48회 관찰되었다. 간투사(I)는 사전평가에서 0.48회였으며, 치료 중 최고 4.1회까지 증가하였으나 사후평가 에서는 0.45 회로 감소되었다. 미완성/수정(UR)의 경우 사전평가 에서 1.45 회였으나 치료 중 감소와 증가를 같이 보이며 사후평가 에서는 0.9회 관찰되었다. 반복1(R1)의 경우, 사전평가에서는 관 찰되지 않았으나 치료 중 1.49 회까지 증가한 후 사후평가에서는 다시 관찰되지 않았다.

비정상적 비유창성은 사전평가에는 7.25 회 관찰되었으나 치 료 중 전체적인 감소를 보였으며 14 회기에서는 1.37 회, 사후평가 에서는 1.37 회 관찰되었다. 이와 같은 비정상적 비유창성의 변 
Table 1. Disfluency frequency of participant 1

\begin{tabular}{|c|c|c|c|c|c|c|c|c|c|c|c|c|c|}
\hline & \multicolumn{5}{|c|}{ Normal disfluency } & \multicolumn{7}{|c|}{ Abnormal disfluency } & \multirow{2}{*}{$\begin{array}{c}\text { Total } \\
\text { disfluency }\end{array}$} \\
\hline & $\mathrm{H}$ & $\mathrm{I}$ & UR & $\mathrm{R} 1$ & ND-T & $\mathrm{Ha}$ & $\mathrm{Ia}$ & URa & R1a & $\mathrm{R} 2$ & $\mathrm{DP}$ & $\mathrm{AD}-\mathrm{T}$ & \\
\hline Pre-tx & 0.48 & 0.48 & 1.45 & 0.00 & 2.41 & 0.00 & 0.00 & 2.42 & 0.00 & 3.86 & 0.97 & 7.25 & 9.66 \\
\hline $\mathrm{Tx}-2$ & 0.00 & 3.48 & 1.49 & 1.49 & 6.46 & 0.00 & 3.98 & 0.00 & 0.00 & 1.49 & 0.49 & 5.96 & 12.42 \\
\hline Tx-4 & 0.96 & 0.96 & 1.44 & 1.44 & 4.80 & 0.48 & 3.85 & 0.00 & 0.00 & 1.92 & 0.96 & 7.21 & 12.01 \\
\hline Tx-6 & 1.50 & 3.00 & 0.50 & 0.50 & 5.50 & 0.00 & 3.50 & 0.00 & 0.00 & 1.50 & 0.00 & 5.00 & 10.50 \\
\hline Tx-8 & 0.45 & 1.82 & 0.45 & 0.45 & 3.17 & 0.00 & 3.18 & 0.00 & 0.00 & 0.91 & 0.45 & 4.54 & 7.71 \\
\hline $\mathrm{Tx}-10$ & 1.46 & 2.93 & 0.49 & 0.00 & 4.88 & 0.00 & 0.00 & 0.00 & 0.00 & 1.95 & 0.98 & 5.93 & 7.81 \\
\hline Tx-12 & 0.50 & 4.50 & 1.00 & 1.00 & 7.00 & 0.00 & 0.00 & 0.00 & 0.00 & 1.00 & 0.50 & 1.50 & 8.50 \\
\hline Tx-14 & 0.91 & 4.10 & 1.37 & 0.91 & 7.29 & 0.00 & 0.00 & 0.00 & 0.00 & 0.46 & 0.91 & 1.37 & 8.66 \\
\hline Post-tx & 4.48 & 0.45 & 0.90 & 0.00 & 5.83 & 0.00 & 0.00 & 0.00 & 0.00 & 0.45 & 0.90 & 1.37 & 7.20 \\
\hline
\end{tabular}

H: hesitation, I: interjection, UR: unfinished word or utterance, R1: repetition1, ND-T: total normal disfluency, Ha: abnormal hesitation, Ia: abnormal interjection, URa: abnormal unfinished word or utterance, R1a: abnormal repetition1, R2: repetition2, DP: disrhythmic phonation, ADT: total abnormal disfluency, Tx: treatment

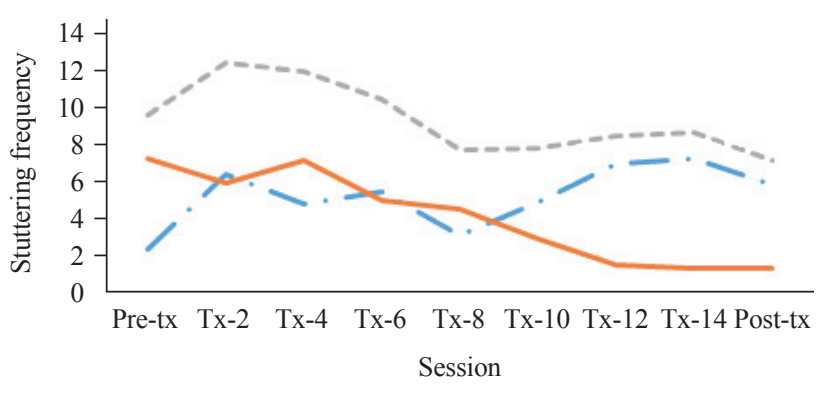

- ND-T $-\mathrm{AD}-\mathrm{T}---\mathrm{T}$-frequency

Figure 1. Changes in normal disfluency, abnormal disfluency, and total disfluency frequency of participant 1. Tx: treatment, ND-T: total normal disfluency, AD-T: total abnormal dsfluency, T-frequency: total disfluency.

화 패턴은 특히 반복2 (R2)에서 관찰되었다. R2는 사전평가에서 3.86회 관찰되었으며 이후 지속적인 감소패턴을 보여 사후평가 에서는 0.45 회 관찰되었다. 반면 비운율적 발성(DP)은 사전평가 0.97회, 사후평가 0.9회로 치료 중 변화가 크게 나타나지 않았 다. 그 밖에 비정상적 주저(Ha), 간투사(Ia), 미완성/수정(Ura)은 치료 중 일시적으로만 관찰되었다. 이에 총 비유창성 빈도 역시 사전평가에서는 총 9.66회 관찰되었으나 치료 초기 증가를 보인 후 전반적으로 감소추세를 보여 사후평가에서는 총 7.2 회 관찰 되었다.

의사소통태도평가의 경우, 사전평가에서는 12 점이었으나 사 후평가에서는 오히려 상승하여 14점이었다.

\section{참여자 2 의 비유창성 빈도의 변화}

참여자 2의 사전평가, 치료 중 평가 총 7 회, 사후평가 등 총
9회의 평가에서 관찰된 100음절 당 각 유형별 비유창성 빈도는 Table 2, Figure 2와 같다.

우선 정상적 비유창성의 경우, 사전평가에서는 100 음절당 4.74회 관찰되었으나, 치료 초기에 증가를 보여 6회기에서 최고 10.84 회 관찰되었다. 이후 감소 추세를 보여 사후평가에서 6.0 회 관찰되었다. 이와 같은 패턴은 모든 정상적 비유창성 유형에서 유사하게 관찰되었으나 주저(H)와 반복 1 (R1)은 사전평가와 비 교, 사후평가에서 더 높은 빈도가 관찰되었으나 간투사(I)와 미 완성/수정(UR)은 사전평가와 비교, 사후평가의 빈도가 낮았다. 예를 들어 간투사(I)와 미완성/수정(UR)은 치료 초기에는 각각 1.42 회, 0.95 회 관찰되었으나 치료 중 최고 7.43회(2회기), 3.45 회 (6회기) 관찰되었으나 이후 감소하였다. 이에 사후평가에서는 각 0.5 회, 0 회 관찰되었다.

비정상적 비유창성 역시, 사전평가와 비교, 치료 초기 증가한 후 이후 지속적인 감소를 보였다. 이와 같은 패턴은 반복 2 (R2) 와 비운율적 발성(DP)에서 관찰되었다. R2의 경우, 사전평가 에서는 4.74회 관찰되었으나 치료 중 최고 7.88회(6회기) 관찰 된 후 사후평가에서는 4.5 회 관찰되었다. DP는 사전평가에서는 7.11 회, 치료 중 최고 12.84 회(2회기), 사후평가에서는 4.5 회 관 찰되었다. 그 밖의 비유창성 유형은 본 연구 참여 중 간헐적으로 관찰되었다. 이에 총 비유창성 빈도 역시 유사한 패턴이 관찰되 었다. 즉 사전평가에서는 총 20.38회 관찰되었으나 치료 초기 증 가를 보인 후 전반적으로 감소 추세를 보여 사후평가에서는 총 16.5 회 관찰되었다.

의사소통태도평가의 경우, 사전평가에서는 13 점이었으나 사 후평가에서는 오히려 상승하여 15점이었다. 
Table 2. Disfluency frequency of participant 2

\begin{tabular}{|c|c|c|c|c|c|c|c|c|c|c|c|c|c|}
\hline & \multicolumn{5}{|c|}{ Normal disfluency } & \multicolumn{7}{|c|}{ Abnormal disfluency } & \multirow{2}{*}{$\begin{array}{c}\text { Total } \\
\text { disfluency }\end{array}$} \\
\hline & $\mathrm{H}$ & I & UR & R1 & ND-T & $\mathrm{Ha}$ & Ia & URa & R1a & $\mathrm{R} 2$ & $\mathrm{DP}$ & $\mathrm{AD}-\mathrm{T}$ & \\
\hline Pre-tx & 0.95 & 1.42 & 0.95 & 1.42 & 4.74 & 0.95 & 2.37 & 0.00 & 0.47 & 4.74 & 7.11 & 15.64 & 20.38 \\
\hline Tx-2 & 1.49 & 7.43 & 1.10 & 0.00 & 10.02 & 0.00 & 0.50 & 0.00 & 0.00 & 5.00 & 12.87 & 18.37 & 28.39 \\
\hline $\mathrm{Tx}-4$ & 4.71 & 1.42 & 1.42 & 1.89 & 9.44 & 1.89 & 0.00 & 0.00 & 0.00 & 5.19 & 10.85 & 17.93 & 27.37 \\
\hline Tx-6 & 1.97 & 2.96 & 3.45 & 2.46 & 10.84 & 1.48 & 0.00 & 0.00 & 0.00 & 7.88 & 6.90 & 16.26 & 27.10 \\
\hline Tx-8 & 2.84 & 2.37 & 1.90 & 1.90 & 9.01 & 0.95 & 0.47 & 0.00 & 0.00 & 5.69 & 7.11 & 14.22 & 23.23 \\
\hline Tx-10 & 1.08 & 4.32 & 1.08 & 1.62 & 8.10 & 0.00 & 1.08 & 1.08 & 1.08 & 5.41 & 4.32 & 12.97 & 21.07 \\
\hline Tx-12 & 0.50 & 2.48 & 1.98 & 0.99 & 5.95 & 0.00 & 0.50 & 0.00 & 0.00 & 5.45 & 7.92 & 13.87 & 19.82 \\
\hline Tx-14 & 2.45 & 0.00 & 0.98 & 1.96 & 5.39 & 0.00 & 0.00 & 1.96 & 0.00 & 4.90 & 5.88 & 12.74 & 18.13 \\
\hline Post-tx & 2.00 & 0.50 & 0.00 & 3.50 & 6.00 & 0.50 & 0.00 & 0.50 & 0.50 & 4.50 & 4.50 & 10.50 & 16.50 \\
\hline
\end{tabular}

H: hesitation, I: interjection, UR: unfinished word or utterance, R1: repetition1, ND-T: total normal disfluency, Ha: abnormal hesitation, Ia: abnormal interjection, URa: abnormal unfinished word or utterance, R1a: abnormal repetition1, R2: repetition2, DP: disrhythmic phonation, ADT: total abnormal disfluency, Tx: treatment

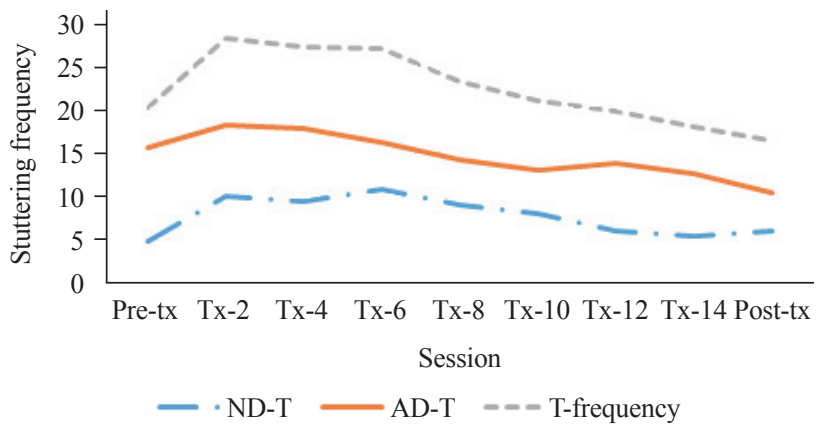

Figure 2. Changes in normal disfluency, abnormal disfluency, and total disfluency frequency of participant 2. Tx: treatment, ND-T: total normal disfluency, AD-T: total abnormal dsfluency, T-frequency: total disfluency.

\section{DISCUSSIONS}

본 연구는 난타를 활용한 말더듬치료가 지적장애를 동반한 말더듬 성인의 비유창성 변화에 어떠한 영향을 주는지 사례보고 를 하고자 하였다. 이를 위하여 총 15 회의 난타를 활용한 말더듬 치료를 두 명의 지적장애를 동반한 말더듬 성인에게 제공하였다. 이들은 전반적으로 비유창성의 감소를 보였으며 이를 보다 자세 히 논의하면 다음과 같다.

본 연구 결과는 구어운동 협응 향상활동이 말더듬치료에 효 과적일 수 있다는 점을 시사한다. 전술한 바와 같이 말더듬의 원 인은 여러 가지가 있을 수 있으나 다양한 조음 산출기관의 구어 운동 협응 부족이 그 원인일 수 있다. 일반적으로 난타활동은 손 움직임 등과 같은 근육 움직임의 협응을 목표로 한다. 하지만 본 연구에서는 난타활동에 구어활동을 결합하였다. 이와 같은 난
타활동과 구어활동의 결합을 통하여 본 연구에서는 말더듬 성인 의 조음기관의 협응을 향상시키고자 하였으며 본 연구 참여자는 구어 협응 능력의 향상을 통하여 비유창성 빈도의 감소를 보인 것으로 추측된다.

특히 이와 관련하여 본 연구의 참여자는 치료 초기에 비유창 성의 빈도가 증가하는 양상을 보였는데 이는 본 프로그램 초기 에는 말 산출 과제가 아닌 행동을 대상으로 하는 난타활동이 주 를 이루었기 때문인 것으로 생각된다. 전술하였듯이 본 연구에서 사용한 치료 프로그램에는 크게 두 가지 목표가 있는데 치료 초 기에는 행동 관련 목표였으며 중반 이후에 난타와 말 산출 과제 가 연결되었다. 즉 이러한 결과는 말더듬치료에서는 단순히 행동 의 협응 개선이 아니라 말 산출 기제의 협응 향상이 중요할 수 있 다는 점을 시사한다.

더불어 치료 초기의 비유창성 증가는 난타활동을 활용한 음 악치료의 부수적인 효과일 수 있다. 전술한 바와 같이 난타활동 의 부수적인 효과로는 스트레스 감소, 자신감 증가, 이로 인한 표 현의 증가일 수 있다. 이에 이러한 난타활동의 부수적인 치료효 과로 인하여 참여자의 발화 시도와 발화량 등이 증가하여 비유 창성이 증가하였을 가능성이 있다. 이와 관련하여 말더듬 성인의 경우, 회피 등의 감소로 인한 발화의 증가와 이에 따른 일시적인 비유창성의 증가가 치료 초기에는 진전의 지표일 수 있다고 제시 되기도 하였다(Manning, 2010). 하지만 본 연구에서는 아쉽게 도 의사소통태도를 제외한 다른 내적 특성과 전반적인 발화량 등과 같은 지표를 측정하지 않았다. 이후 후속 연구에서는 이와 같은 지표를 측정하여 말더듬치료의 다면적인 변화양상을 살펴 보는 것이 필요할 것이다.

특히 본 연구 참여자는 지적장애가 있는 말더듬 성인이었는 
데, 이들의 지적능력 등을 고려할 때 난타활동이 특히 말 산출 관련 운동 조절능력에 도움이 되었을 것으로 예상한다. 전술 하였듯이 말더듬치료 책략 중 유창성 증진법은 말속도 조절 등 과 같은 다양한 유창성 향상 기법을 활용하여 대상자의 유창성 을 증진시키는 것을 목표로 한다. 특히 본 연구에 참여한 지적 장애 말더듬 성인의 경우, 일반적인 구두 명령을 포함한 과제로 는 유창성 증진행동과 관련된 목표와 활동을 성공적으로 수행 하는데 어려움을 겪을 수도 있다. 이에 청각적 자극 및 활동, 신 체적 활동 등을 포함한 종합적인 치료활동이 이들의 유창성 증 진에 도움이 되었을 것으로 생각된다. 이와 관련하여 말더듬이 다면적 장애이기에 유창성 증진뿐 아니라 심리적인 특성의 변화 를 위하여 인지치료 등을 포함하는 것 역시 제안되기도 하였다 (Manning, 2010). 하지만 지적장애가 있는 말더듬 성인의 경우, 인지치료 등을 진행하는 데 어려움이 있을 수 있으므로 본 연구 에서 진행한 것과 같은 다양한 종류의 치료 프로그램을 통합적 으로 사용하여 행동 변화를 촉진할 수 있을 것이다.

본 연구 결과는 또한 말더듬치료를 통한 유창성 변화가 각 개 인에 따라서 다르게 나타날 수 있다는, 즉 개별적 특성이 나타난 다는 점을 강조한다. 본 연구에는 두 명의 지적장애 말더듬 성인 이 참여하였는데 이들이 보이는 변화의 패턴은 서로 상이하였다. 예를 들어 참여자 1 의 경우, 치료 중 정상적 비유창성의 증가와 비정상적 비유창성의 감소를 보였다. 반면 참여자 2 는 정상적 비 유창성보다는 비정상적 비유창성에서 더 큰 변화의 패턴을 보였 다. 진전을 나타내는 지표로는 우선 비정상적 비유창성의 감소일 수 있으며 이와 더불어 정상적 비유창성의 증가 역시 진전의 지 표일 수 있다. 이는 특히 본 연구 참여자와 같이 지적장애 등으로 인하여 언어문제가 있는 경우, 비정상적 비유창성의 감소와 더불 어 발화의 증가로 인하여 정상적 비유창성이 증가하였을 수 있 다. 본 연구에서는 언어 관련 변화 패턴을 측정하지 않았으며 언 어발달이 주요 중재목표가 아니었다. 하지만 후속 연구에서는 언 어문제가 있는 대상자가 말더듬 중재를 통하여 나타내는 언어 표 현의 변화를 살펴보고 이러한 언어적 변화가 비유창성 변화와 어떠한 관련성이 있는지 살펴볼 수 있을 것이다.

또한 본 연구 결과는 말더듬 성인의 치료가 장기적이어야 한다 는 점을 강조한다. 본 연구에서는 주 1 2회 정도의 치료를 총 15 회 기 진행하였으며, 이렇게 상대적으로 짧은 치료에서도 비유창성 의 변화가 관찰되었다. 특히 참여자 1 의 경우, 사후평가에서 비 정상적 비유창성 빈도가 100 음절당 3 회 미만, 총 비유창성 빈 도가 100 음절당 10 회 미만이었으며, 이는 일반적인 유창성장애 평가 결과, 정상적으로 판단될 수 있는 수준이다(Guitar, 2018). 반면 참여자 2는 사후평가에서 비정상적 비유창성 빈도가 100 음 절당 10 회 정도였다. 이는 아마도 참여자 1 과 비교하여 참여자 2 가 비유창성 빈도, 언어발달 등의 측면에서 더 어려움을 보였기
때문인 것으로 생각된다. 이와 관련하여 일반적으로 말더듬 성인 의 치료는 매우 오랜 시간이 필요하기에 이들이 보다 장기적으로 어떠한 변화를 보이는지에 대한 연구가 더 필요할 것이다.

비록 난타를 활용한 말더듬치료를 통하여 본 연구에 참여한 지적장애 말더듬 성인의 유창성에 변화가 나타났지만 의사소통 태도에서는 긍정적인 변화가 관찰되지 않았다. 전술하였듯이 난 타를 활용한 치료는 성취감, 자신감 등과 같은 내적 특성의 변화 에도 도움을 주는 것으로 보고되었다(Heo, 2013). 이와 관련하 여 의사소통태도와 같은 말더듬 관련 내적 특성의 변화는 행동 의 변화보다 더 어려우며 시간이 더 걸릴 수 있다. 또한 본 연구 에서 사용한 말더듬치료는 내적 특성의 변화보다는 외적 특성의 변화를 주된 목표로 하였기에 본 연구 참여자의 의사소통태도에 서는 긍정적인 변화가 나타나지 않았던 것으로 추측된다.

본 연구가 지적장애 말더듬 성인을 대상으로 실시한 난타활동 이 유창성 증진에 효과적일 수 있다는 점을 시사하지만 다음과 같은 제한점을 갖는다. 우선 본 연구는 두 명의 참여자를 대상으 로 한 사례 연구이기에 이러한 결과를 일반화시키기에는 제한점 이 있다. 특히 본 연구에서는 치료사와 참여자의 대화를 대상으 로 비유창성의 빈도 변화를 측정하였다. 하지만 이러한 비유창 성의 변화가 보다 더 다양한 상황과 대상에서 일반화되는지 살 펴보아야 할 것이다. 또한 본 연구는 사례 연구이기에 통계적 검 증절차를 실시하지 않았으나 후속 연구에서는 보다 더 많은 참 여자를 대상으로, 통계 검증을 실시할 필요가 있을 것이다.

비록 소수이기는 하지만 지적장애가 있는 말더듬 성인을 대상 으로 난타활동을 활용한 말더듬치료를 제공한 결과, 이들은 비 유창성의 감소 패턴을 보였다. 특히 본 연구에서는 일반적인 난 타활동에 말 관련 과제를 결합하였는데 이러한 결과는 말더듬치 료는 대상자의 특성에 따라 다양하고도 개별적으로 실시하여야 한다는 점을 강조한다.

중심 단어: 난타, 말더듬, 지적장애, 성인.

\section{Ethical Statement}

This study was approved by the Institutional Review Board of Daegu Catholic University (IRB \# CUIRB-2019-0058).

\section{Acknowledgments \\ N/A}

\section{Declaration of Conflicting Interests}

There are no conflict of interests. 
Funding

N/A

\section{Author Contributions}

Conceptualization: Yeong Hye Park, Kyungjae Lee, Seong Hee Choi. Data curation: Yeong Hye Park. Formal analysis: Yeong Hye Park, Kyungjae Lee. Investigation: Yeong Hye Park. Methodology: Yeong Hye Park. Project administration: Yeong Hye Park. Resources: Yeong Hye Park. Software: Yeong Hye Park. Supervision: Kyungjae Lee, Seong Hee Choi. Validation: Kyungjae Lee, Seong Hee Choi. Visualization: Yeong Hye Park, Kyungjae Lee, Seong Hee Choi. Writing_original draft: Yeong Hye Park, Kyungjae Lee, Seong Hee Choi. Writing-review \& editing: Yeong Hye Park, Kyungjae Lee, Seong Hee Choi. Approval of final manuscript: Yeong Hye Park, Kyungjae Lee, Seong Hee Choi.

\section{ORCIDiD}

Yeong Hye Park https://orcid.org/0000-0002-3625-3291

Kyungjae Lee https://orcid.org/0000-0002-6811-1212

Seong Hee Choi ～https://orcid.org/0000-0003-2365-6187

\section{REFERENCES}

Caruso, A. J., Conture, E. G., \& Colton, R. H. (1988). Selected temporal parameters of coordination associated with stuttering in children. Journal of Fluency Disorders, 13(1), 57-82.

Cho, J. M. (2007). Therapeutic use of music for stuttering children. Journal of Music and Human Behavior, 4(1), 21-30.

Choi, P. I. (1993). Effects of music learning on vocalization, sensorymotor coodination, and social behavior development of trainable mentallay retarded children (Unpublished master's thesis). Chonju: Woosok University.

Conture, E. G. \& Melnick, K. S. (1999). Parent-child group approach to stuttering in preschool children. In Onslow M. \& Packman A. The Handbook of Early Stuttering Intervention (pp.17-51). San Diego, CA: Singular Publishing Group.

Gottwald, S. R. (2010). Stuttering prevention and early intervention: A multidimensional approach. In Guitar B. \&. McCauley R. Treatment of Stuttering: Established and Emerging Interventions (pp.91-117). Philadelphia, PA: Wolters-Kluwer.

Guitar, B. (2018). Stuttering: An Integrated Approach to Its Nature and Treatment. (4th ed.). Baltimore, MD: Lippincott Williams \& Wilkin.
Heo, S. (2013). The effect of activities of nanta using nanta drum on stressand self-esteem of students with intellectual disabilities (Unpublished master's thesis). Busan: Inje University.

Ingham, R. J. (1984). Stuttering and Behavior Therapy: Current Status and Experimental Foundations. San Diego, CA: College-Hill Press.

Jang, M. H. (2015). A study regarding the effect of nanta activity on the happiness level and self-esteem of middle-high school students with intellectual disability (Unpublished master's thesis). Gwangju: Chosun University.

Jung, H. J. (2015). Human Behavior and Music. Seoul: Hakjisa.

Kim. C. M. (2010). The effect of nanta on the eye-hand coordination ability of children with mental retardati (Unpublished master's thesis). Gyeongsan: Daegu University.

Kim, D. Y. (2017). Relationship between rhythm aptitude and body coordination of children from 7 to 9 years old (Unpublished master's thesis). Seoul: Seoul National University of Education.

Kim, S. J. (2003). The effect of percussion training on the sensory and motor skills for children with developmental and multiple disabilities (Unpublished master's thesis). Gyeongsan: Daegu University.

Kim, S. J., Go, I. J., \& Gwon, H. G. (2002). Introduction to Music Therapy: Theory and Practice. Seoul: Gwon Hye Gyeong Music Therapy Center.

Kim, Y. T., Hong, G. H., Kim, K. H., Jang, H. S., \& Lee, J. Y. (2009). Receptive and Expressive Vocabulary Test (REVT). Seoul: Seoul Community Rehabilitation Center.

Lee, J. E. (2014). The effect of nanta activities on the socio-emotional development of preschool children at child care centers (Unpublished master's thesis). Seoul: Myongji University.

Loucks, T. M., De Nil, L. F., \& Sasisekaran, J. (2007). Jaw-phonatory coordination in chronic developmental stuttering. Journal of Communication Disorders, 40(3), 257-272.

Manning, W. H. (2010). Clinical Decision Making in Fluency Disorders. (3rd ed.). Clifton Park, NY: Delmar Cengage Learning.

Olander, L., Smith, A., \& Zelaznik, H. N. (2010). Evidence that a motor timing deficit is a factor in the development of stuttering. Journal of Speech, Language, and Hearing research, 53(4), 876-886.

Packman, A., Onslow, M., \& Menzies, R. (2000). Novel speech patterns and the treatment of stuttering. Disability and Rehabilitation, 22(12), 65-79.

Shin, H. J. (2010). The effect of speech rhythm play using the orff approach on the development rhythmic sense-focused on the first grade in an elementary school (Unpublished master's thesis). Cheonan: Baekseo University.

Sim, H. S., Shin, M. J., \& Lee, E. J. (2010). Paradise-Fluency AssessmentII. (2nd ed.). Seoul: Paradise Welfare Foundation.

Van Riper, C. (1997). The Treatment of Stuttering. Englewood Cliffs, NJ: Prentice-Hall.

Zebrowski, P. M. (1994). Duration of sound prolongation and sound/syllable repetition in children who stutter: Preliminary observations. Journal of Speech and Hearing Research, 37(2), 254263. 


\section{APPENDIX}

주요 치료 목표 및 활동

\begin{tabular}{|c|c|}
\hline 회기 & 주요 치료 목표 및 활동 \\
\hline 1회기 & $\begin{array}{l}\text { * 프로그램 소개하기 } \\
\text { * 긴장 이완 및 신체활동 }\end{array}$ \\
\hline 2회기 & $\begin{array}{l}\text { * 난타의 기본자세 익히기 } \\
\text { - 자유롭게 북 치며 탐색하기 } \\
\text { - 북채잡기, 북 치기 배우기 } \\
\text { - 강·약 치기 }\end{array}$ \\
\hline 3회기 & $\begin{array}{l}\text { * 난타의 기본자세 익히기 } \\
\text { - 양손타법 익히기 } \\
\text { - 2( }(J=2), 3(J=3), 4(J=4) \text { 박 구분하기 }\end{array}$ \\
\hline 4회기 & $\begin{array}{l}\text { * 몸 장단 습득하기 } \\
\text { - 1-4회 북 치기 } \\
\text { - 양손 타법 익히기 } \\
\text { - 강약 변화시키며 북 치기 }\end{array}$ \\
\hline 5회기 & $\begin{array}{l}\text { * 몸 장단 습득하기 } \\
\text { - 1 8회 북 치기 } \\
\text { - 강약 변화시키며 북 치기 }\end{array}$ \\
\hline 6회기 & $\begin{array}{l}\text { * 음절 수에 맞추어 북 치기 } \\
\text { - 1음절 단어 말하며 북 치기 } \\
\text { * 리듬과 박자에 맞추어 북 치기 } \\
\text { - 동요에 맞추어 북 치기 }\end{array}$ \\
\hline 7회기 & $\begin{array}{l}\text { * 음절 수에 맞추어 북 치기 } \\
\text { - 2음절 단어 말하며 북 치기 } \\
\text { * 리듬과 박자에 맞추어 북 치기 } \\
\text { - 동요에 맞추어 북 치기(2/4 박자) }\end{array}$ \\
\hline 8회기 & $\begin{array}{l}\text { * 음절 수에 맞추어 북 치기 } \\
\text { - 3음절 단어 말하며 북 치기 } \\
\text { * 리듬과 박자에 맞추어 북 치기 } \\
\text { - 동요에 맞추어 북 치기(3/4 박자) }\end{array}$ \\
\hline 9회기 & $\begin{array}{l}\text { * 음절 수에 맞추어 북 치기 } \\
\text { - 4음절 단어/구 말하며 북 치기 } \\
\text { * 리듬과 박자에 맞추어 북 치기 } \\
\text { - 동요에 맞추어 북 치기(4/4 박자) }\end{array}$ \\
\hline
\end{tabular}

\begin{tabular}{|c|c|}
\hline 회기 & 주요 치료 목표 및 활동 \\
\hline 10회기 & $\begin{array}{l}\text { *음절 수에 맞추어 북 치기 } \\
\text { - 5 6음절 구 말하며 북 치기 } \\
\text { * 리듬과 박자에 맞추어 북 치기 } \\
\text { - 동요에 맞추어 북 치기(4/4 박자) }\end{array}$ \\
\hline 11회기 & $\begin{array}{l}\text { * 음절 수에 맞추어 북 치기 } \\
\text { - 7 8음절 구 말하며 북 치기 } \\
\text { * 리듬과 박자에 맞추어 북 치기 } \\
\text { - 동요에 맞추어 북 치기(4/4 박자) }\end{array}$ \\
\hline 12회기 & $\begin{array}{l}\text { * 음절 수에 맞추어 북 치기 } \\
\text { - 9 10음절 문장 말하며 북 치기 } \\
\text { * 리듬과 박자에 맞추어 북 치기 } \\
\text { - 동요에 맞추어 북 치기(4/4 박자) }\end{array}$ \\
\hline 13회기 & $\begin{array}{l}\text { *음절 수에 맞추어 북 치기 } \\
\text { - 자발화하면서 북 치기 } \\
\text { * 리듬과 박자에 맞추어 북 치기 } \\
\text { - 동요에 맞추어 북 치기(다양한 박자) } \\
\text { - 즉흥 연주하기 }\end{array}$ \\
\hline 14 회기 & $\begin{array}{l}\text { * 음절 수에 맞추어 북 치기 } \\
\text { - 자발화하면서 북 치기 } \\
\text { * 리듬과 박자에 맞추어 북 치기 } \\
\text { - 동요에 맞추어 북 치기(다양한 박자) } \\
\text { - 즉흥 연주하기 }\end{array}$ \\
\hline 15회기 & $\begin{array}{l}\text { * 음절 수에 맞추어 북 치기 } \\
\text { - 자발화하면서 북 치기 } \\
\text { * 리듬과 박자에 맞추어 북 치기 } \\
\text { - 동요에 맞추어 북 치기(다양한 박자) } \\
\text { - 즉흥 연주하기 }\end{array}$ \\
\hline
\end{tabular}

